\title{
A Typology of Father Parenting in The Migrant Workers Family and Effect on Character of Children
}

\author{
Wilodati, D. Budimansyah, S. Adiwikarta, Y. Ruyadi \\ Universitas Pendidikan Indonesia \\ wilodati@upi.edu
}

\begin{abstract}
Parenting is a model of interaction between parents and children, which aims to foster the child's character. In general, parenting is done by both parents, especially mothers. However, in families where the mother latches become foreign workers abroad, the responsibility and the implementation of the childcare switch entirely to the father. Typology of a father's parenting is different, thought to be an effect also on differences in the character of their children. This study aimed to get an overview of the typology of father parenting in the family Labor Women, and its influence on the character of their children. Because intends to reveal in depth the social situation, then selected a qualitative approach, in order to describe the reality of the situation at the site of the study. Participants of this study are the father, whose wife was into women workers in Saudi Arabia, along with their children. Data collection techniques, is through observation; deep interview; and literature studies. Data analysis techniques, beginning with data reduction, data display, and conclusion drawing / verification. Along with the data collection, performed triangulation of data sources, which is one component of credibility test data in qualitative research. According to the research there appears to be three types of parenting that is owned by the father in the family environment of the female labor force, i.e. Authoritarian parenting; Permissive; and Authoritative. Based on the results of the research can be stated, that the type of parenting a different father would produce children's character is different. It should be used as a reference by the parents in the choice of the typology of parenting that will be applied to children.
\end{abstract}

Key Words: child character; family; the typology of father parenting

\section{INTRODUCTION}

This study examines the typology of father parenting in the family Women Labor, and its influence on the character of their children. The definition of parenting by Zubaedi is, "The pattern of interaction between children and parents that include physical needs, (such as eating and drinking) and psychological needs such as security and affection), and dissemination of the norms prevailing in the community for children can live in harmony with the environment ". [1]

Parenting is one of the most relevant perspectives in the study of relationships between parents and children. [2]

Parenting style captures two important elements of parenting: parental responsiveness and parental demandingness (Maccoby \& Martin, 1983). Parental responsiveness refers to "the extent to which parents intentionally foster individuality, self-regulation, and self-assertion by being attuned, supportive, and acquiescent to children's special needs and demands" (Baumrind, 1991). Parental demandingness refers to "the claims parents make on children to become integrated into the family whole, by their maturity demands, supervision, disciplinary efforts and willingness to confront the child who disobeys" (Baumrind, 1991). [3]

Relying on these underlying dimensions, Baumrind (1991) distinguished four key parenting styles: authoritative, authoritative, authoritarian, permissive, and uninvolved. Authoritative parents combine high levels of support and control; this is considered the most effective parenting style for promoting children's well-being (Baumrind, 1991; Marsiglio, Amato, Day, \& Lamb, 2000; Simons, \& Conger, 2007). Authoritarian parents provide high control and low control. [4]

Authoritarian parenting style suggested that children are expected to be submissive to their parent's demands, while parents were expected to be strict, direct, and emotionally detached. Permissive parenting style like the name implies connotes less parental restrictions or limits on the child. The implication of this is that children are expected to regulate their own activities. An authoritative parenting style similar to authoritarian parenting entailed clear and firm direction to the children. However, the difference between the two similar parenting styles lies in the moderating discipline with warmth, reason, and flexibility as ensued by authoritative parenting (Kawamura, Frost, \& Marmatz, 2002; Pong, Hao, \& Gardner, 2005). [5]

Parenting parents believed to be influential on the formation of the character of the child, because the child first retain the basics of personality in a family environment. Understanding character, stated by Majid and Andayani as well:

Character is the nature, or things that are so fundamental that exist in a person. Often people call it a character or temperament. No matter what name this 
character is the nature of the human mind that affect all of your thoughts and actions. The characters can be found in a person's attitudes, to himself, to others, to the tasks entrusted to it and in other situations. [6]

Supposedly, parenting in the family environment was conducted jointly by the father and mother. Although in reality, its implementation was done by more dominant mothers rather than the father in everyday life. This traditional picture of the role of men and women in family life, which tends to still showed an element of difference between men and women is assumed. As reflected in the statement Supartiningsih the following, "... The traditional gender division of Labor (the base of the gender division of labor) puts the Division of labor, women at home (domestic sector) and men worked outside the home (public sector)". [7]

However, such circumstances do not occur in the environment of the village of Sindangmulya sub-district of Karawang Kutawaluya, where a number of Moms who were their profession as the labor of women in Saudi Arabia. With a contract for two years, and afterward can be updated again. This of course makes the mother cannot carry out its obligations as a nanny in the period. By itself, the responsibility of parenting the children completely reverts to the father, which is in fact still working to meet the needs of his family.

Through this research is expected illustrated the importance of the application of the corresponding typology of parenting by fathers in caring for their children, because it will also affect their character.

\section{RESEARCH METHOD}

This study intends to understand the typology of parenting and its influence on the character of the children in a family of migrant workers in the village of Sindangmulya the sub-District of Kutawaluya, Karawang , which later described with words that describe social reality by using a qualitative approach, the understanding expressed by Satori and Komariah as the following, "The qualitative research is a research approach that reveal certain social situations to describe reality correctly, formed by the words based on the techniques of collecting and analyzing relevant data obtained from the natural situation". [8]

This research subject is a family of migrant workers that are the focus of this study. Two primary data source used in this study is the respondent (husband whose wife becomes migrant workers, as well as their children); and informants base is the village chief, village officials, as well as RW and RT where respondents live); and the principal informant, that relatives are involved in the care of children in the family environment of the migrant workers. Secondary data were obtained from various sources, both governmental and non-governmental, ranging from village, sub-district to district, published or unpublished. The location of this research is a family Labor Woman in the village Sindangmulya District of Kutawaluya, Karawang, West Java.

Data collection techniques used in this study were the observation; interviewing; and documentation. In order to collect data in this study, also conducted triangulation technique, which the researchers tried to combine all three sources of data in this study is the father; child; and relatives are involved in the care of children in the family of the migrant workers. Triangulation is once again intended as well as to test the validity of the data, in particular the credibility of the data, so that the data obtained is consistent, thorough, and definitely

It is, in accordance with the opinion of Sugiyono in:

Triangulation is defined as data collection techniques that are combining various data collection techniques and data sources that already exist. When researchers collecting data with triangulation, then in fact the researchers collected data at the same time test the credibility of the data, IE checks the credibility of the data with a variety of data collection techniques and data sources. [9]

Patto expressed by triangulation,"can build on the strengths of each type of data collection while minimizing the weakness in any single approach". [10]

Form of triangulation that researchers do is reflected in the following picture:

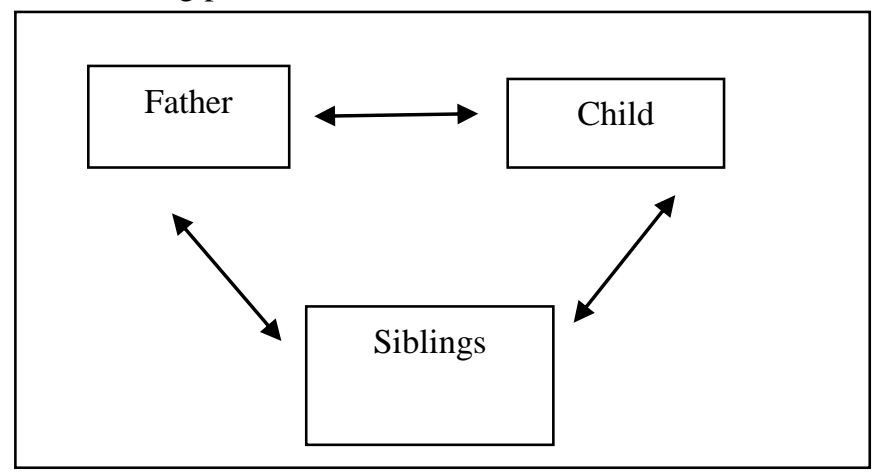

Fig. 1. Source: Modify from Sugiyono [11]

The technique of data analysis refers to the qualitative data analysis techniques according to Miles and Huberman (2007), which consists of three flow of activities that occur simultaneously, namely, "data reduction, data presentation, drawing conclusions / verification". [12]

\section{RESULT}

Based on observations and interviews conducted, it can be stated that there are three different typologies of parenting fathers in the family of the migrant workers, namely:

1) The first parenting, with characteristics such as:

- Giving freedom with certain limitations while parenting.

- Parenting with great affection, warmth, tenderness, and familiarity.

- Explain in detail the purpose of establishing a rule, and why children should obey him;

- Contract for harmonious communication between father and children

- Given the opportunity to the children to develop his independence

- Respect the decisions, opinions, and the personality of the child, to the extent it is good for them; in order that the children gain confidence, feeling 
valued and acknowledged his existence by his father.

2) The second parenting, with characteristics such as:

- Giving freedom to children in attitude and behavior.

- Very involved in the child's life

- Never demanded anything against children

- Never did control-control when caring for children;

- When children make mistakes, never punishing.

- Rarely participate interfering in the private lives of children.

- Relations with children are very close;

- All the desire and willingness of the child always obeyed.

- Neither control when caring for children

- The number of rules applied, and everything must be complied children without exception and compromise

- Never communicate clearly rules made for children

3) The third parenting, with characteristics such as:

- The child must comply with all rules set by the father

- Do not provide opportunities for children to ask the rules are applied.

- When a child in violation of existing regulations, father warned explicitly, even punished him physically.

- The father decides all decisions related to the needs of children.

- All decisions related to the child's life are determined solely by the father.

Baumrind (1971) has developed a model of parenting style, which is accepted and followed by most of the researchers. She proposed that parents fall into one of the four categories, but according to Buri (1991), whittin the model proposed by baumrind three distinct prototypes of parental authority have been offered. According to Buri, they are as follows:

1) Authoritarian: These parents value control and unquestioning obedience. They try to make children conform to a set standard of conduct, and punish them forcefully for acting contrary to that standard. They are more detached and less warm than other parents. Their children tend to be more discontented, withdrawn and distrustful. Authoritarian parenting also termed as dictatorial or harsh, is low on warmth/nurturance, strict on discipline, high in parent to child communication, but low in child to parent communication and high on expectation. This parent shows little affection and "seem aloof from their children" (Berger, 2001).

2) Authoritative: These parents respect child's individuality, while at the same time stress social reality. They direct their children's activities rationally, pay attention to the issues rather than a child's fear of punishment or loss of love. They are loving, consistent, demanding and respectful of children's independent decisions, but they are firm in maintaining standards and willing to impose limited punishment. They explain to the reasoning behind the stands taken and encourage verbal give and take. They combine control with encouragement. Their children apparently feel secure in knowing that they are loved and what is expected of them. The preschool children of authoritative parents tend to be most self reliant, self controlled, self assertive, exploratory and content.

3) Permissive: Permissive parents find it hard to set clear limits and provide structure. They are inconsistent disciplinarians (Huxley, 1998) and reward bad behavior regularly (Dworkin, 1997). Children are not pushed and enforced to obey guidelines or standards even when they do exist (Barakat and Clark, 1999). [13]

Referring to the Baumrind opinion, based on their characteristic parenting unity belongs to the type of authoritative parenting. When connected with the attitude of the father in this study, among other things seemed out of respect for the presence of her children, then I will support all children's decisions, as long as the resulting good to them. Control, attention, guidance, and direction of the child's personal life was always done with great affection.

Furthermore, parenting both of the above results, including to the type of permissive parenting. It is apparent, from the attitude shown dad that never requires children to obey the rules which it adopted, even though the father communicating in detail to the child. The father seemed to let the child to follow what they want. According to the father, the child's desire must be made to be obeyed and the views of the child must always be heard. Although the relationship between father and son are very close, but at the time parenting, father never control them because they believe the children already know what they should do. Supervision is done, but in rudimentary only.

Meanwhile, the third parenting, can be categorized into the type of authoritarian parenting. Based on the results of the study seem, since the beginning of the father has set rules that must be implemented in everyday life. Children who have to obey all the wishes of parents. Children are taught to respond to the wishes of the father, and stick to it, without having to be explained at length, as the forms and respect his efforts in taking care of them. As the head of the family, father performs strict control when caring for children. Father never interfere in the private affairs of the child. They should be able to do all of their own affairs, not accustomed to relying on others.

Furthermore, each type of parenting that father used, it appears the image of the characters of her children as follows:

1) Character produced by the father of authoritative parenting, is as follows:

- Capable of aligning the expectations of parents and personal desire.

- Easy to get along with anyone. 
- Be able to determine when to learn, and when it's time to play.

- Grow as a communicative and adoptive child.

- Appears as independent child and have the highest confidence.

2) The character generated by the user's father Permissive parenting is as follows:

- Less able to respect the opinions of others.

- Must constantly be obeyed her wishes.

- Including child personality freely, his behavior somewhat unruly / controlled, wants to behave as they please.

- Not including children timidly, like against anybody who displeased heart.

- Are less able to socialize with people.

- Difficult to associate

- Lazy learning, academic achievement is

- Less good less independent, tend to rely on others.

3) The character generated by the user's father Authoritarian parenting is as follows:

- Less responsible.

- Often behave aggressively, especially if his wishes were not obeyed.

- Less good at communicating with others.

- The child is not conforming, often seen as a rebellious son, and like to rebut parent command.

- Difficult to forgive the mistakes of others.

- Like it wants to win its own (selfish), all his wishes must be quickly met.

- Seeking attention by way of a sulk and denied counsel parents.

- Tend to withdraw from the Association

In general, the character generated by the three typologies of parenting fathers in the family of the migrant workers, consistent with the results Baumrind about style treatment of parents (parenting style) and its impact on children's behavior, the following:

TABLE I. The Influence of "PARENTING StYlE" ON THE ChILD BEHAVIOR

\begin{tabular}{|c|c|c|}
\hline $\begin{array}{l}\text { PARENTING } \\
\text { STYLES }\end{array}$ & $\begin{array}{c}\text { ATTITUDE OR } \\
\text { BEHAVIOR OF } \\
\text { PARENTS }\end{array}$ & $\begin{array}{l}\text { CHILD BEHAVIOR } \\
\text { PROFILE }\end{array}$ \\
\hline 1. Authoritarian & \begin{tabular}{|l} 
1. \\
The attitude of ' \\
acceptance ' is \\
low, but high \\
control. \\
2. Physically \\
punishing. \\
3. \\
Being \\
commanded \\
(requires/rule \\
the kid to do \\
something no- \\
compromise) \\
Be rigid (hard
\end{tabular} & \begin{tabular}{|ll} 
1. & Irritability \\
2. & Cowards \\
3. & Moody, unhappy \\
4. & Easily to affected \\
5. & Do not have a clear \\
6. & future direction \\
Unfriendly
\end{tabular} \\
\hline
\end{tabular}

\begin{tabular}{|c|c|c|}
\hline & $\begin{array}{l}\text { attitude). } \\
\text { 5. } \begin{array}{l}\text { Emotional and } \\
\text { tend to be } \\
\text { rejected }\end{array}\end{array}$ & \\
\hline 2. Permissive & $\begin{array}{l}\text { 1. The attitude of } \\
\text { 'acceptance' } \\
\text { high, but low } \\
\text { control. } \\
\text { 2. Give freedom to } \\
\text { the child's } \\
\text { expressed } \\
\text { wishes }\end{array}$ & $\begin{array}{ll}\text { 1. } & \text { Being impulsive } \\
\text { and aggressive. } \\
\text { 2. Rebellious. } \\
\text { 3. Lack of confidence } \\
\text { and self-control. } \\
\text { 4. Domineering. } \\
\text { 5. No clear direction } \\
\text { of his life. } \\
\text { 6. Lower achievement }\end{array}$ \\
\hline 3. Authoritative & $\begin{array}{l}\text { 1. The attitude of } \\
\text { acceptance and } \\
\text { high control } \\
\text { 2. Responsive to } \\
\text { the needs of } \\
\text { children } \\
\text { 3. Encourage the } \\
\text { child to express } \\
\text { an opinion or } \\
\text { question } \\
\text { 4. Provides an } \\
\text { explanation of } \\
\text { the impact of } \\
\text { the good deed } \\
\text { and the bad. }\end{array}$ & $\begin{array}{ll}\text { 1. } & \text { Be friendly } \\
\text { 2. Have the } & \text { confidence } \\
\text { 3. Being able to } \\
\text { control themselves } \\
\text { 4. Be polite } \\
\text { 5. Cooperates } \\
\text { 6. Have a sense of } \\
\text { curiosity is high } \\
\text { 7. Have } \\
\text { goals/directions } \\
\text { clear living } \\
\text { Oriented towards } \\
\text { achievements }\end{array}$ \\
\hline
\end{tabular}

a. Source: Yusuf [14]

Based on the results of research conducted in the migrant family can be stated, that the father of the different typologies of parenting can produce different characters in the child.

\section{RESULT}

One of the main goals of parenting for their children is the formation of good character. In a family of migrant workers, where the responsibility for the care of children is fully transferred to the father, because the mother is working abroad, the father should still be able to look after their children well too.

The findings stated that the different typology of father parenting a, will produce a different character of the child, should be used as a reference by parents to choose appropriate parenting typology, in order to influence the growth of good character in their children themselves.

In further research, is expected to be reviewed various typologies of parenting influence of fathers in the family of migrant workers, and their effects on the lives of children associated with the world of formal education, for example ideals pursue higher education; motivation to excel, and so on.

\section{REFERENCE}

[1] Zubaedi. Desain Pendidikan Karakter Konsepsi dan Aplikasinya dalam Lembaga Pendidikan, Jakarta : Kencana, 2011, 158

[2] Isabel Martinez, Jose Fernando Garcia. Parenting Styles and Adolescents 'Self-Esteem in Brazil' (J) Psychological Reports, 2007, 100, 731-745

[3] Dr. A.H.M. Vijaya Laxmi, Dr. Manjula Kadapatti. Analysis of Parenting Styles and Interpersonal Relationship among Adolescents (J) International Journal of Scientific and Research Publications, 2012, 2, 96-100

[4] Kim Bastaits, Koen Ponnet, Christine Van Peer and Dimitri Mortelmans. The Parenting Styles of Divorced Fathers and Their Predictors (J) Journal of Social and Personal Relationship, 2015, $32(5), 557-559$ 
[5] Abdorreza Kordi dan Rozumah Baharudin, Parenting Attitude and Style and Its Effect on Children's School Achievements (J) International Journal of Psychological Studies 2010, 2 (2), 217-222

[6] Majid, A. dan Andayani, D. Pendidikan Karakter Perspektif Islam, Bandung : PT Remaja Rosdakarya, 2012, 12

[7] Supartiningsih. Peran Ganda perempuan Sebuah Analisis Filosofis Kritis, Jurnal Filsafat, April 2003, Jilid 33, Nomor 1, Universitas Gajah Mada Yogyakarta, 2003, 43

[8] Satori, Dj. dan Komariah, A. Metodologi Penelitian Kualitatif. Bandung: Alfabeta, 2012, 24

[9] Sugiyono. Metode Penelitian Kuantitatif, Kualitatif dan R \& D, Bandung: Alfabeta, 2012, 241; 241; 273

[10] Sugiyono. Metode Penelitian Kuantitatif, Kualitatif dan R \& D, Bandung: Alfabeta, 2012, 241; 241; 273

[11] Sugiyono. Metode Penelitian Kuantitatif, Kualitatif dan R \& D, Bandung: Alfabeta, 2012, 241; 241; 273

[12] Miles, M. B dan A. Michael H. Analisis Data Kualitatif Buku Sumber Tentang Metode-metode Baru, Jakarta : UI-Press, 2007, 16-21

[13] N. Hasnain, Bushra Faraz, Parul Adlakha. Self-Esteem and Happiness of Children and Mother of Different Parental Authority (J) The International Journal of Humanities \& Social Studies, 2013, (1), 1-6

[14] Yusuf L.N.S. Psikologi Perkembangan Anak \& Remaja. Bandung : PT. Remaja Rosda Karya, 2011, 51-52 